\title{
31. 頸部嘀清術後の病態生理（実験的研究）
}

\author{
広戸幾一郎・野村和・未吉 楠雄
}

\section{研究目的}

表（1）は教室臨床例に和ける頸部晾清術施行の142 側について検討したるので，臨床的に頸りンバ節堙脹を 認めたものである，敦清術側の再発 18 側，非廓清側で は19 側炕認められ，予想外に高率に䞏められるのであ る.

図（1）は喉頭癌症例の ${ }^{198} \mathrm{Au}$ scintigram である。 右図は敦清術前（左頸リンパ虚脹を認めていた），左図 は左頸部廓清術後のものであるが，術後反刘側頸部への ${ }^{198} \mathrm{Au}$ の移動を認める。表 (2) は頸部リンパ節尰脹泟 例に和ける噺清術前後の scintigram の結果である，術 前反対側頸部への移動は全く認められないが，廓清術後 では 4 例に反対側頸部への移動を認めたのである．本研 究の目的は斯万臨床的結果に基づくものである.

\section{研究方法}

成熟家鬼 33 例飞よる耳翼りンパ管遮断後に扣ける遮 断耳翼の病態変化および領域組織の諸变化を観察した。 本实験に先立つて正常家鬼耳翼リンハ路の解剖学的走行 を確めた後，耳翼附着部におけるリンパ管をすべて遮断 し経静眽的に色素注入後のリンパ路㵂溯側，非遮断側耳 翼の色素消退の経時的過程を光䉓管に上り測定しその値 を量的に比校換算した。他方りンハ液の移動は ${ }^{198} \mathrm{Au}$ を使用した scintigram に上り前华駼同よう之も経時的 に観察比較した，又、リン只路遮断後，未端耳骍に器質 変化を生じた一部実駼家鬼症例については病理組織学的 飞拾索した。

\section{実験成績}

正常家鬼耳翼リンパ路は外側耳翼に执いてては翼りン ハ管は動静脈に沿つて耳翼附着部では $3 〜 4$ 本に 集り，
内側耳翼においては同よう て 2本のリンバ管として結 集する。(四 2 schema)

実験家鬼における経静脈的色素注入後の遮䉼，扣よび 非遮断耳翼に扣ける色素消退の過程を絽時的曲線で示す

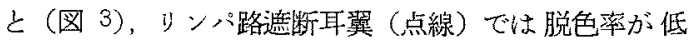
く正常耳翼 (笑線)では高くこの両曲線の差がリンパ路 を経た色素消退量である。

耳巽に ${ }^{198} \mathrm{Au}$ を注入し scintigram を作成すると （図 4）右側遮断例では遮断部に ${ }^{198} \mathrm{Au}$ の貯溜を認め左 側正常耳では顎下リンパ節に相当した2らの陰影を認め る. 同よら实験を更に profile scanning で検したのが （図 5)である，左側正常侧の曲線は 3 ケの山型曲線が 示す如く，右上り耳翼 ${ }^{168} \mathrm{Au}$ 注入部，顎下りンパ節部， 拈よび肝蔵曲線として認められる。他方右側遮断耳の曲 線は2ケの曲線から成り，右より耳翼 ${ }^{198} \mathrm{Au}$ 注入部， 次いで徐々比下降して耳翼遮断部にて再びやや上帠し曲 線はそのまま消退し肝臟曲線を認めない。

耳翼リンハ管遮断により耳翼末端の器質的变化を生ず るものを相当数認めるが（図 6)，更にこれ等症例の組 織像をみると（図 7) に示声如くで炎定所見は殆んど認

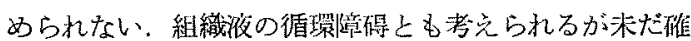
証は得ていない。

結語

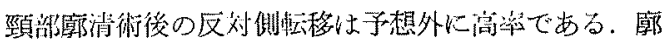
清術による正常りンパ流の乱れ，又仙，遮断後のリンパ 液循裐，遮断後領域組織の病態变化に関する経静脈色素 注入， scintigram 使用によるリンパ液の動物奏験過程 について報告した 


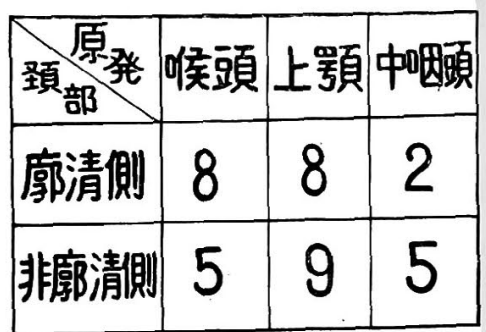

表 1

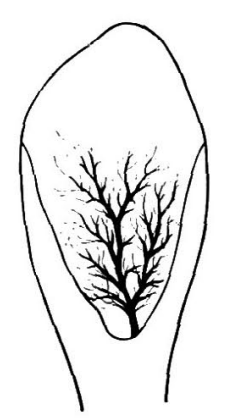

图 2
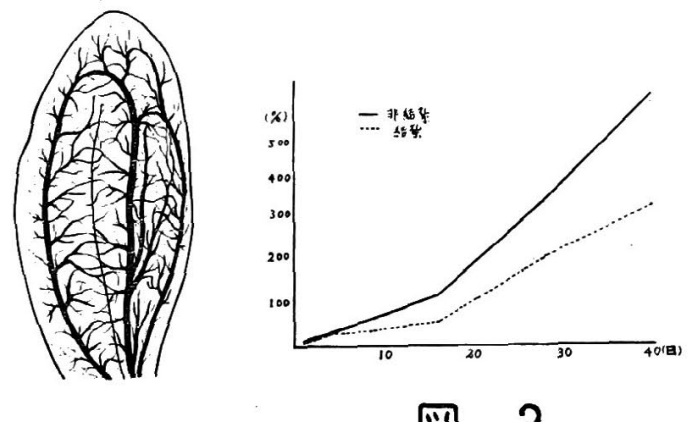

図 3
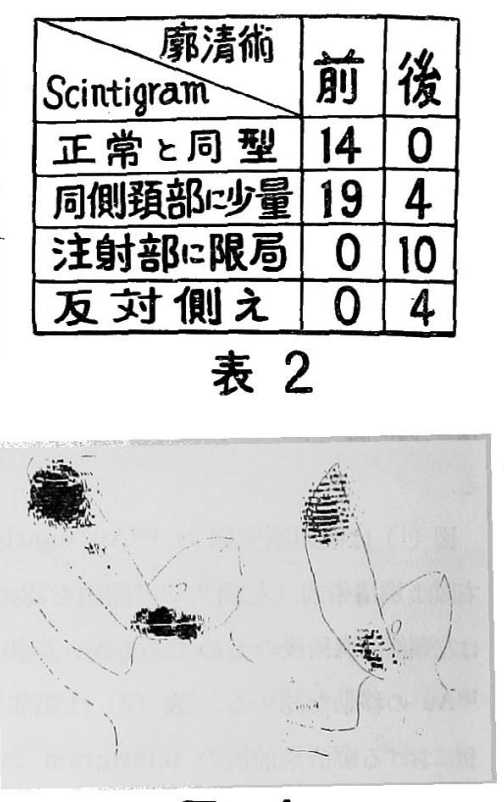

图 4

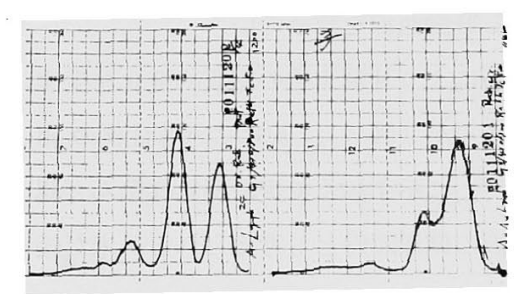

図 5

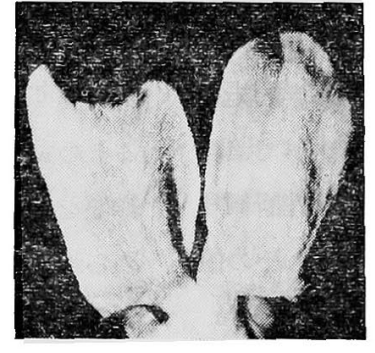

図 6

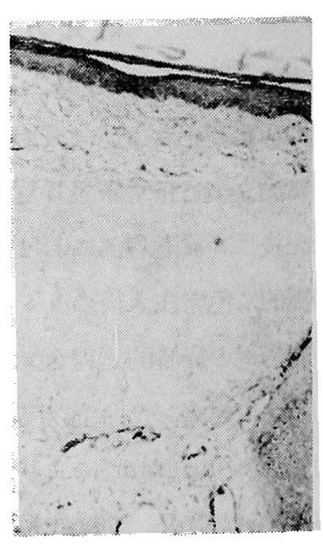

四 7

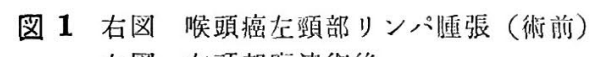
左図左頸部磓清術後

图 2 家雨耳翼リンパ管 Schema

图 3 耳翼色䋕消退曲線

図 4 実験家乘 Scintigram（右遮断側，左正常侧）
图 5 " "] P profile Scanning (右遮断側, 左正常側) 図 6 実験家臣（右正常側, 左遮断侧)

図 7 耳翼欠損部組織像

表 1 頸部房清術例（142）例の術後再発部位 表 2 頸部部掯術前後の Scintigra!. 